Original Research Paper

\title{
Pregnancy Rate and Reproductive Disorders Examination of Inseminated Brahman Cross Cows by Rectal Palpation and Ultrasonography
}

\author{
${ }^{1,2}$ Mohamad Ervandi, ${ }^{3}$ Muhammad Nur Ihsan, ${ }^{3}$ Sri Wahjuningsih and ${ }^{3}$ Trinil Susilawati \\ ${ }^{I}$ Faculty of Animal Science, University of Brawijaya, Malang, Indonesia \\ ${ }^{2}$ Faculty of Agricultural Science, Muhammadiyah University of Gorontalo, Gorontalo, Indonesia \\ ${ }^{3}$ Department of Animal Production, Faculty of Animal Science, University of Brawijaya, Malang, Indonesia
}

\author{
Article history \\ Received: 14-12-2019 \\ Revised: 02-03-2020 \\ Accepted: 27-03-2020 \\ Corresponding Author: \\ Mohamad Ervandi \\ Faculty of Agricultural \\ Science, Muhammadiyah \\ University of Gorontalo, \\ Gorontalo 96181, Indonesia \\ Email: ervandi_husain@yahoo.co.id
}

\begin{abstract}
Pregnancy is a condition when a fetus began to develop in the uterus of the cow. Early pregnancy detection becomes important as it would determine the success of breeding management as well as to achieve the best productivity. This study aimed to evaluate and observe the pregnancy rate and reproductive disorders of Brahman Cross (BX) cows and compare the results to the Ultrasonography (USG) observation. The materials of the study were $80 \mathrm{BX}$ cows selected through a purposive sampling method with the following criteria: aged $2-3$ years, weighed $300-500 \mathrm{~kg}$, has at least calved once and had the body condition score (BCS) at 4-7 (in 1-9 scale). This study was conducted as experimental research, with $40 \mathrm{BX}$ cows were artificially inseminated with Ongole crossbred (PO) semen at $0-2 \mathrm{~h}$ interval and the other $40 \mathrm{BX}$ cows were at 8-10 h interval from the estrous detection. All of the BX cows were firstly synchronized with PGF2 $\alpha$ (LUTALYSE) and then inseminated with PO semen ( $>40 \%$ motility) as according to the Indonesian standard. The pregnancy rate of the BX cows was observed through rectal palpation and 17ß-estradiol hormone observation and further examined for the reproductive disorders by using USG. The obtained data were then analyzed descriptively and the results showed that $0-2 \mathrm{~h}$ insemination had a higher success of pregnancy $(32.5 \%)$ compared to the 8-10 h interval (27.5\%). Moreover, the highest 17ßestradiol in the inseminated BX cows was at $5,765 \mathrm{ng} / \mathrm{ml}$, while the lowest was at is $0.41 \mathrm{ng} / \mathrm{ml}$. The USG observation showed that $6 \mathrm{BX}$ cows $(7 \%)$ in this study had a follicular cyst, 2 BX cows $(2.25 \%)$ had persistent corpus luteum and $1 \mathrm{BX}$ cows $(1.25 \%)$ had ovarian hypofunction.
\end{abstract}

Keywords: Brahman Cross Cows, Reproductive Disorders, Rectal Palpation, Ultrasonography, 17 $\beta$-Estradiol

\section{Introduction}

Beef cattle have been the main meat producers and source of the nutritional animal-based protein. The demand for beef consumption in Indonesia has been increasing along with the increased human population and could not be fulfilled solely from the local breeds. The breeding of local cattle with other breeds with higher meat production provides an alternative way to fulfill the demand for meat consumption. Brahman Cross (BX) cattle is one of the crossbreed cattle developed in Indonesia aimed to achieve the goal. The BX cattle had shown good adaptability to the tropical climates, survivability to ectoparasites, as well as good body weight gain and productivity even fed with a low quality feed. The production performance of $\mathrm{BX}$ cattle, thus showed its potential to be reared in Indonesia in order to increase domestic meat production (Kuswati and Susilawati, 2016).

The common breeding practice in Indonesia is by natural breeding or Artificial Insemination (AI). The AI has shown many beneficiaries compared to the natural breeding, however, the success of AI would be determined by several factors such as heat detection, inseminating skills and the body condition of the cows (Saacke, 2008; Roelofs et al., 2010; Susilawati, 2011). Silent heat is commonly cases found on the farm which 
will prevent farmers to make the correct decision to determine the time for artificial insemination. Yekti et al. (2017) described that silent heat is the condition where cows did not express clear signs of heat due to the low estrogen level.

Pregnancy is defined as the post-mating physiological period that resulted in the conception and then followed with embryo development into a fetus until parturition (Hafez and Hafez, 2000). Various pregnancy diagnosis can be done depending on the reproductive anatomy and physiological condition of the livestock. In large livestock, such as cows, the most practical and reliable diagnosis is by detecting rectal palpation or by using Ultrasonography (USG) (Fricke, 2005).

The current conditions showed that the AI of BX cows still had the low success of pregnancy. Research by Annashru et al. (2017) showed that different time of AI would affect the calving to non-return rate of $\mathrm{BX}$ cows, with $0-4 \mathrm{~h}$ insemination interval from detected estrous was higher $(70 \%)$ compared to the $8-12 \mathrm{~h}(37.14 \%)$. The condition thus showed that the time interval of insemination could affect the success of AI as well. In this study, we observe the different time intervals of insemination to the pregnancy rate and occurred reproductive disorders in $\mathrm{BX}$ cows.

\section{Materials and Methods}

\section{Materials}

The materials of this study were 80 Brahman Cross (BX) cows selected through a purposive sampling method with the following criteria: aged 2-3 years, weighed $300-500 \mathrm{~kg}$, have at least calved once and had the body condition score (BCS) at 4-7 (in 1-9 scale).

\section{Methods}

This study was conducted as experimental research. All of the BX cows were firstly synchronized with PGF2 $\alpha$ (LUTALYSE) and then inseminated with PO semen ( $>40 \%$ motility) as according to the Indonesia standard. The first treatment (P1) were $40 \mathrm{BX}$ cows inseminated at $0-2 \mathrm{~h}$ intervals from estrous detection, while the second treatment (P2) were 40 BX cows inseminated at 8-10 h intervals from estrous detection. The pregnancy rate of the BX cows was observed through rectal palpation at 90-days after insemination, while the $17 \beta$-estradiol hormone measurement was done by firstly taking the blood sample of BX cows from the jugular vein in the tail area at 90-days after insemination. The sample was then measured for the $17 \beta$-estradiol hormone by using commercial ELISA kit (Bioassay Tecnology Laboratory, Shanghai) according to the manufacturer's instruction: http://www.btlaboratory.com/product/bovine-estrogen-elisa-kit-2/. The USG (Mindray DP-50) observation was done by following Royal et al. (2000). The pregnancy rate was analyzed descriptively and formulated as follows:

$$
\frac{\text { Total pregnant BX cows }}{\text { Total performed insemination }} \times 100 \%
$$

The Non-Return Rate (NRR) of the inseminated BX cows were also observed frequently at 18 -days $\left(\mathrm{NRR}_{1}\right)$, 36-days $\left(\mathrm{NRR}_{2}\right)$ and 54-days $\left(\mathrm{NRR}_{3}\right)$ after insemination to detect early failed pregnancy.

\section{Results}

\section{The Pregnancy Rate of the Brahman Cross Cows}

The pregnancy observation by using rectal palpation of BX cows in this study is presented in Table 1 .

The results showed that the overall successful pregnancy of artificially inseminated BX cows both at $\mathrm{P} 1$ and $\mathrm{P} 2$ was $30 \%$. Furthermore, the pregnancy rate at $\mathrm{P} 1$ or $0-2 \mathrm{~h}$ insemination interval $(32.5 \%)$ was higher compared to the $\mathrm{P} 2$ or $8-10 \mathrm{~h}$ interval $(27.5 \%)$. The low successful pregnancy of the BX cows was caused by disorders in the ovary, especially ovarian hypofunction, follicular cyst, persistent corpus luteum and endometritis (Fig. 1 to 3 ).

The rectal palpation showed that 56 out of 80 inseminated BX cows were failed to pregnant. Purposive sampling was done by selecting $18 \mathrm{BX}$ cows, consisted of 6 BX cows with positive (+) NRR and rectal palpation; 6 BX cows with positive $(+)$ NRR but negative $(-)$ rectal palpation; and $6 \mathrm{BX}$ cows with negative (-) NRR and rectal palpation, for USG examination. The estradiol 17- $\beta$ levels of each cow were measured to understand the relationship of the hormone concentration to the status of pregnancy of the BX cows' ovary (Table 2).

\section{Ultrasonography Examination}

It can be seen that the highest $17 \beta$-estradiol concentration levels of the BX cows were $5,765 \mathrm{ng} / \mathrm{ml}$ while the lowest was $0.41 \mathrm{ng} / \mathrm{ml}$, with each BX cow had varying $17 \beta$-estradiol concentration levels. The observed $17 \beta$-estradiol concentration levels in this study are higher than the finding by Domènech et al. (2011) in dairy cows, which showed $17 \beta$-estradiol concentration levels at $26.75 \pm 8.63 \mathrm{pg} / \mathrm{ml}$ or equals to $2,675 \mathrm{ng} / \mathrm{ml}$; and Kajaysri (2006) which showed the 17 $\beta$-estradiol concentration levels in Friesian crossbreed dairy cows were $2,786 \mathrm{ng} / \mathrm{ml}$.

\section{Ultrasonography Observation}

Physiological observation of the BX cows' ovary by using ultrasonography showed that 6 cows (7\%) had a follicular cyst, 2 cows $(2.25 \%)$ had persistent corpus luteum and 1 cow $(1.25 \%)$ had ovarian hypofunction. 
Table 1: The pregnancy rate of Brahman Cross cows at the different insemination time interval

\section{Treatment}

Pregnancy Rate

\begin{tabular}{lll}
\hline P1 & P2 & Total \\
\hline $13(32.5 \%)$ & $11(27.5 \%)$ & $24(30 \%)$ \\
$27(67.5 \%)$ & $29(72.5 \%)$ & $56(70 \%)$ \\
$40(100 \%)$ & $40(100 \%)$ & $80(100 \%)$
\end{tabular}

Successful pregnancy $(\%)$

Failed pregnancy $(\%)$

Note: $\mathrm{P} 1=\mathrm{BX}$ cows inseminated at $0-2 \mathrm{~h}$ interval from estrous detection; $\mathrm{P} 2=\mathrm{BX}$ cows inseminated at $8-10 \mathrm{~h}$ interval from estrous detection

Table 2: Status of pregnancy examinations of the Brahman Cross cows at different insemination time interval

\begin{tabular}{|c|c|c|c|c|c|c|}
\hline \multirow[b]{2}{*}{ No } & \multicolumn{6}{|c|}{ Non-Return Rate } \\
\hline & $\mathrm{NRR}_{1}$ & $\mathrm{NRR}_{2}$ & $\mathrm{NRR}_{3}$ & Rectal palpation & concentration $(\mathrm{ng} / \mathrm{ml})$ & Result \\
\hline 1 & + & + & + & - & 1.13 & Persistent corpus luteum was found \\
\hline 2 & + & + & + & - & 0.41 & Ovarian hypofunction was found \\
\hline 3 & + & + & + & - & 2,618 & Suspected early embryonic death \\
\hline 4 & - & - & - & - & 4,371 & Follicular cyst was found \\
\hline 5 & - & - & - & - & 4,217 & Follicular cyst was found \\
\hline 6 & - & - & - & - & 5,765 & Follicular cyst was found \\
\hline 7 & + & + & + & + & 1,745 & 6-months pregnancy \\
\hline 8 & + & + & + & + & 1,611 & 6-months pregnancy \\
\hline 9 & + & + & + & + & 1,664 & 5-months pregnancy \\
\hline 10 & + & + & + & - & 2,517 & Suspected early embryonic death \\
\hline 11 & + & + & + & - & 1.26 & Persistent corpus luteum was found \\
\hline 12 & + & + & + & - & 2,575 & Suspected early embryonic death \\
\hline 13 & - & - & - & - & 3,052 & Follicular cyst was found \\
\hline 14 & - & - & - & - & 5,459 & Follicular cyst was found \\
\hline 15 & - & - & - & - & 4,437 & Follicular cyst was found \\
\hline 16 & + & + & + & + & 1,590 & 4-months pregnancy \\
\hline 17 & + & + & + & + & 1,312 & 5 -months pregnancy \\
\hline 18 & + & + & + & + & 1,611 & 4-months pregnancy \\
\hline
\end{tabular}

Description: The non-return rate observations were performed at 18-days $\left(\mathrm{NRR}_{1}\right)$, 36-days $\left(\mathrm{NRR}_{2}\right)$ and 54 -days $\left(\mathrm{NRR}_{3}\right)$ after insemination. The rectal palpation and ultrasonography examinations were performed 90 -days after insemination.
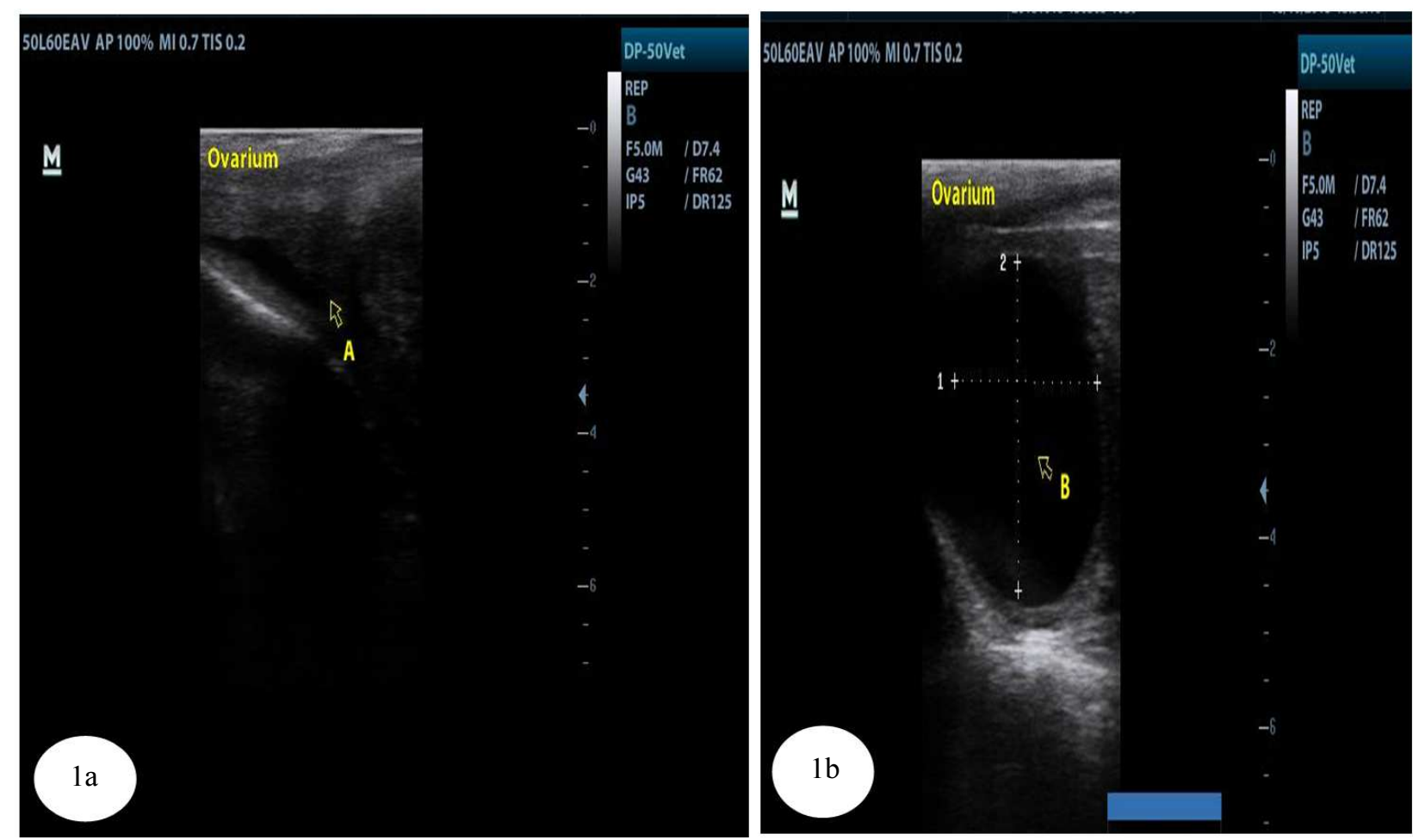

Fig. 1: (a) No follicle was found in the ovary and ovarian hypofunction has occurred; (b) Follicular cyst was found 


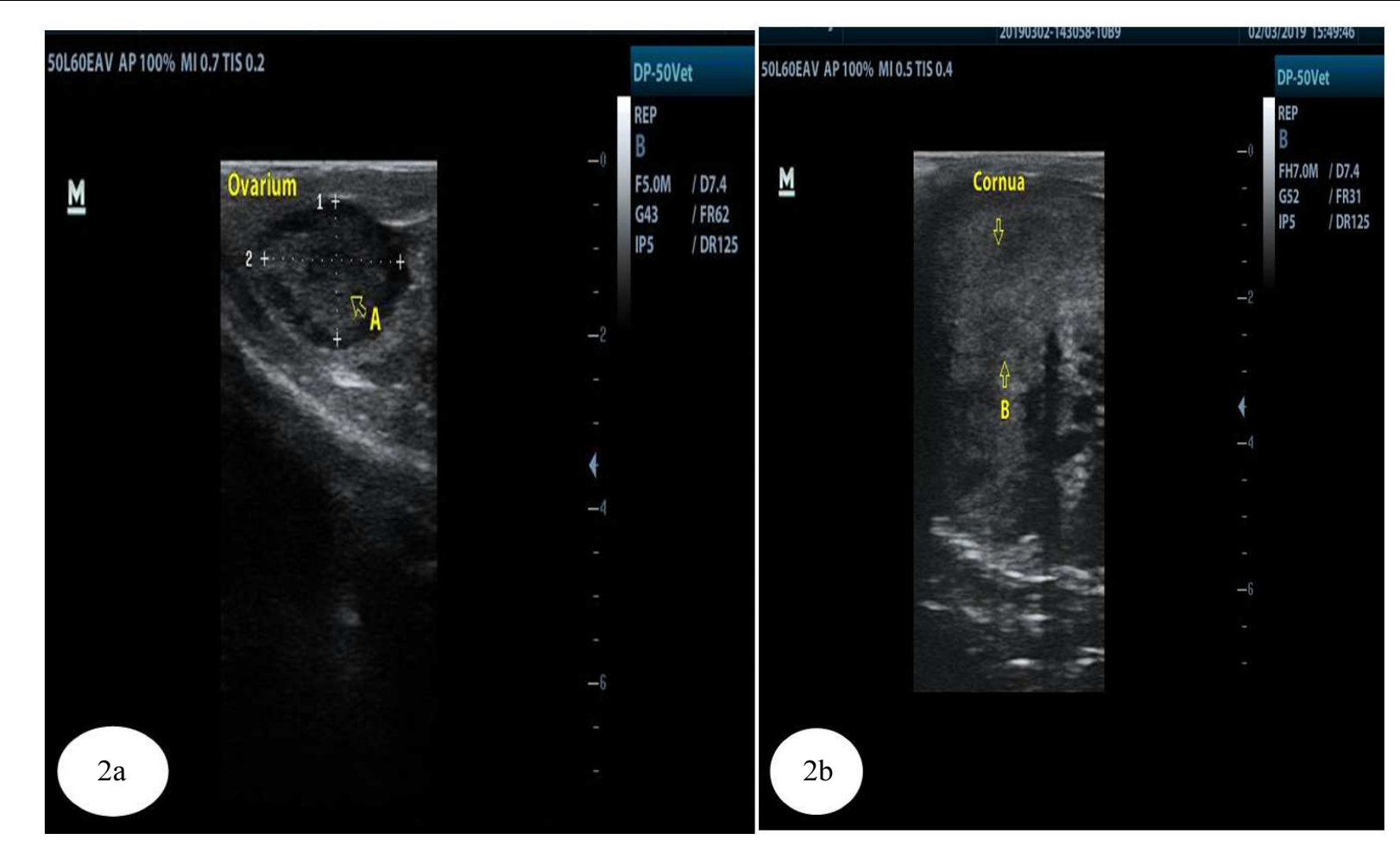

Fig. 2: (a) Persistent corpus luteum was found; (b) Endometritis is found in the uterus

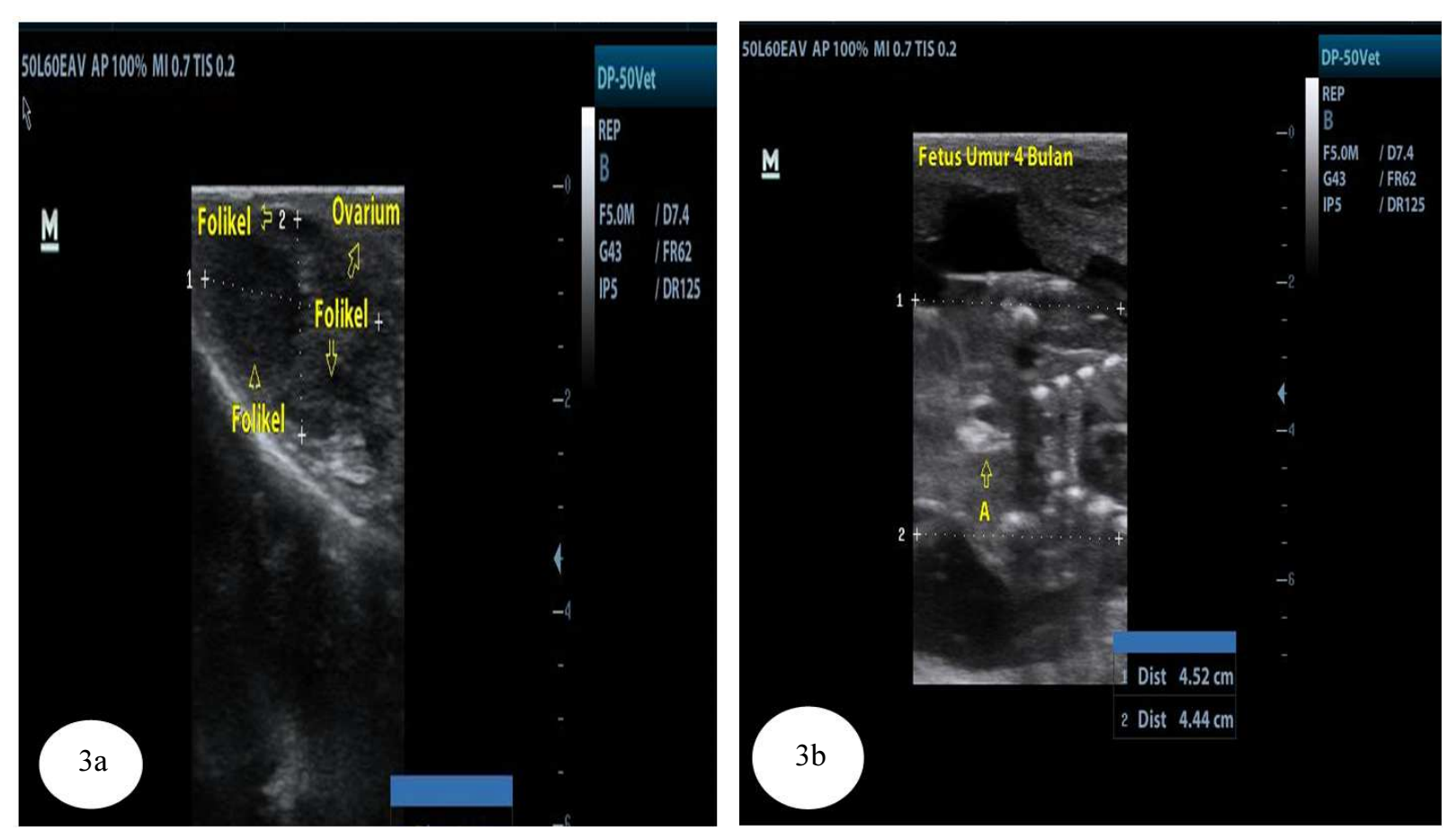

Fig. 3: (a) Normal ovary with the follicle; (b) 4-months fetus

In Fig. 1, it can be seen that the BX cows had ovarian hypofunction, characterized by the slippery ovarian surface during rectal palpation due to the undeveloped follicles and corpus luteum. It is allegedly caused by the feed deficiency of the BX cows which resulted in impaired FSH and LH secretion. Endometritis and persistent corpus luteum with $2.59 \mathrm{~mm}$ in length and $1.58 \mathrm{~mm}$ in width were also found in the BX cows in this 
study (Fig. 2). The USG observation with normal ovary and 4-months fetus can be seen in Fig. 3.

\section{Discussion}

\section{Pregnancy rate of the Brahman Cross cows}

In this study, energy deficiency from the feed is known to contribute to the low rate of successful pregnancy, noting that it would affect the FSH and LH hormone secretion, thus disrupt ovulation, fertilization and embryonic development as well as causing ovarian hypofunction. Boland and Lonergan (2003) reported that nutrient deficiencies can reduce fertility, whereas Yekti et al. (2017) added that low feed quality and quantity will cause sub-fertilization, especially in exotic crossbreed cows. Zare et al. (2008) showed the impact of improved nutrition would initiate the hypothalamus to affect the anterior pituitary gland to release gonadotropins and growth hormones, thus affect ovulation followed by increased estradiol 17- $\beta$ levels. Another known factor that contributes to the successful pregnancy is the proper heat detection of the inseminated cows. The heat occurrence on the acceptor is affected by gonadotropin and FSH hormone induction, which stimulates the development of primary and de Graff follicles, especially granulosa cells which, then produce the 17- $\beta$ estradiol and LH hormone and stimulates ovulation (Hafez and Hafez, 2000).

\section{Relationship between Estradiol 17- $\beta$ Concentration and Ultrasonography Examination}

A large follicular cyst was found in the BX cows' ovary (Fig. 1), which then caused nymphomanic condition (continuous heat) and affect the $17 \beta$-estradiol levels. This is in accordance with Nora et al. (2018), who showed that large follicles, as well as the occurrence of the follicular cyst, would result in high $17 \beta$-estradiol levels. The occurrence of a follicular cyst could be detected if the follicle is larger than $25 \mathrm{~mm}$ without any corpus luteum whether on both left or right ovary (Murayama et al., 2015).

The blood sample collection in this study was carried out at 9 AM before the ultrasonography (USG examination. The time for blood collection is essential as the cows would have a varying physiological condition, thus affect its $17 \beta$-estradiol levels. Hafez and Hafez (2000) mentioned that during a oestrous cycle, reproductive hormones interact with each other and affect its physiological and behavioral changes of the cow. Hossner (2005) added that hormones are influenced by internal and external factors. The internal factors include the genetic and physiological conditions, while the external factors include nutrition intake and the environment condition.
The ultrasonography observation showed that 6 cows had follicular cysts, 2 cows had persistent corpus luteum and one cow had ovarian hypofunction. The follicular cyst would cause reproductive failure and mostly found with the diameters at more than $2.5 \mathrm{~cm}$, attached in the ovary for 10 days or more, without any presence of corpus luteum. The follicular cyst is known to disrupt ovulation and decreased LH hormone production. Hermadi et al. (2011) explained that follicular cyst will occur due to the lack of LH hormone production, while the FSH hormone remained sufficient, thus stimulate the production of the anovulatory follicle and resulted in nymphomanic condition of the cow. Yekti et al. (2017) added that nymphomania in cow indicates the occurrence of follicular cysts.

Moreover, endometritis and persistent corpus luteum were also found in the BX cows in this study (Fig. 2). This condition was caused by whether infection or high progesterone levels suppress the FSH and LH secretion from the anterior pituitary gland. Research by Ghanem et al. (2015) has elucidate various bacterial infection to the occurrence of endometritis, while Sheldon et al. (2006) showed that high progesterone level in blood contributes to the persistent corpus luteum.

The ovarian hypofunction occurs due to the low FSH and $\mathrm{LH}$ hormones production and resulted in the failure of follicle production in the ovary. Hermadi et al. (2011) stated that the bad physiological condition, as well as long feed deficiency of the cow, would alter the ovarian hypofunction into ovarian atrophy. Moreover, the persistent corpus luteum would occur due to the failed luteolysis and the corpus luteum remained in the ovary in a long time despite the failed pregnancy. All form of the corpus luteum can produce the progesterone hormone, this explains that the BX cows with persistent corpus luteum in this study had high progesterone hormone levels in the blood. Boland and Lonergan (2003) mentioned that nutrition deficiency would reduce the cows' fertility and research by Zare et al. (2008) showed that, the improved nutritional intake would affect the anterior pituitary gland to produce higher gonadotropin and growth hormone, thus resulted in higher ovulation and $17 \beta$-estradiol levels. In addition, Feradis (2014) showed that nutrition deficiency would disrupt the gonadotropin synthesis in the pituitary gland.

\section{Relationship between Non-Return Rate, Estradiol 17- $\beta$ Concentration and Ultrasonography Examination}

In this study, pregnancy examination was done by observing the NRR, rectal palpation and further confirmed by ultrasonography examination. The $17 \beta-$ estradiol levels were also measured to understand its relationship to the status of pregnancy. The ultrasonography observation of the BX cows showed 
various ovarian abnormalities, such as persistent corpus luteum, ovarian hypofunction and follicular cyst. Hafez and Hafez (2000) described that the ovarian hypofunction is caused by the failure of follicular cells to respond to the hormonal stimulation, changes in hormonal secretion, decreased stimulation in the ovarian hypothalamic-pituitary function which resulted in no ovarian activity after calving. The clinical symptoms of follicular cyst include nymphomania (continuous heat), anestrus (silent heat), sacroischiadicum ligament relaxation, vulvar edema and increased uterus size. Noakes et al. (2016) showed that follicular cyst with diameters at 1-3 cm can be felt when touched using rectal palpation. The occurrence of a follicular cyst would cause ovulation failure. Ovulation requires a series of processes at the cellular and subcellular levels involving hormones and factors in the form of complex biochemical compounds (Russell and Robker, 2007). The existence of metabolic infertility is closely related to malnutrition which will lead to the low reproductive performance of cows (Donaldson, 2014). In addition, Dibia et al. (2015) mentioned that another factor that needs to be further observed is the high cases of ovarian hypofunction in productive cows due to crossbreeding.

The occurrence of persistent corpus luteum (Fig. 2a) and endometritis (Fig. 2b) indicates that the BX cows suffer pyometra. Endometritis is caused by the failed PGF $2 \alpha$ production in the endometrium, which then resulted in the failed luteolysis. Santoso et al. (2014) described that persistent corpus luteum often found in cows with reproductive disorders, indicated with continuous progesterone production and longer heat cycle. However, in some cases, cows could still get pregnant, but the fetus would still die to the failure involution (Sayuti et al., 2012; Cuneo et al., 2006). Siregar et al. (2012) described that small follicles (3-8) with a total of fewer than 10 follicles are categorized as dominant follicles, while small follicles with a total of more than 10 follicles were not. This study showed that the examination of dominant follicles is based on its morphology, the results of the study indicate that follicular growth is a dynamic process controlled by local and systematic processes (Fortune et al., 2004). Large follicles that appear during luteolysis will become dominant and subsequently ovulate in the follicular phase (Inskeep, 2004).

Pregnancy is a period from fertilization until giving birth (Frandson et al., 2009). The risk of failed pregnancy would be higher during early pregnancy, specifically at day-2 until day-42 after insemination. The early ultrasonography examination would produce more accurate failed pregnancy detection compared to rectal palpation (De-Vries, 2006). Moreover, feed also known to play important roles in the reproduction process.
Research by Susilawati (2013) showed that feed would affect all cows' activities, starting from the cows' metabolism, growth, lactation and also reproductive activities. Therefore, special concern in nutritional intakes of the cows should be taken, especially in the proteins, carbohydrates, vitamins and mineral intakes, as the deficiency of the compounds would cause continuous reproductive disorders.

\section{Conclusion}

This study concludes that the $0-2 \mathrm{~h}$ artificial insemination interval after estrous detection of $\mathrm{BX}$ cows had a higher pregnancy rate $(32.5 \%)$ compared to $8-10 \mathrm{~h}$ interval (27.5\%). Moreover, the $17 \beta$-estradiol measurement showed that the highest $17 \beta$-estradiol levels of BX cows in this study were at $5,765 \mathrm{ng} / \mathrm{ml}$, while the lowest at $0.41 \mathrm{ng} / \mathrm{ml}$. The ultrasonography observation showed that 6 out of $80 \mathrm{BX}$ cows $(7 \%)$ had ovary abnormalities due to the occurrence of the follicular cyst, 2 cows $(2.25 \%)$ had persistent corpus luteum and 1 cow $(1.25 \%)$ had ovarian hypofunction.

\section{Acknowledgement}

We would like to thank the director and company staff of PT. Pasir Tengah (PT. Widodo Makmur Perkasa) for facilitating the research.

\section{Funding Information}

BUDI-DN Scholarship by the Indonesia Endowment Fund for Education (LPDP Ministry of Finance of the Republic of Indonesia) as the funders of this research.

\section{Author's Contributions}

Mohamad Ervandi and Trinil Susilawati: Designing and conducting the research and writing the manuscript.

Muhammad Nur Ihsan and Sri Wahjuningsih: Collaborating in field research, conducting laboratory analysis and interpreting the obtained data.

\section{Ethics}

This article is original and contains unpublished material. The corresponding author confirms that all of the other authors have read and approved the manuscript and no ethical issues involved.

\section{References}

Annashru, F.A., M.N. Ihsan, A.P.A. Yekti and T. Susilawati, 2017. The effect of differences time in artificial insemination toward successful Brahman Cross pregnancy. J. Ilmu-Ilmu Peternakan, 27: 17-23. DOI: 10.21776/ub.jiip.2017.027.03.03 
Boland, M. and P. Lonergan, 2003. Effects of nutrition on fertility in dairy cows. Adv. Dairy Cattle Technol., 19: 155-160.

Cuneo, S.P., C.S. Card and E.J. Bicknell, 2006. Disease of beef catle asociated with post-calving and breeding. The University of Wisconsin, Madison.

De-Vries, A., 2006. Economic value of pregnancy in dairy cattle. J. Dairy Sci., 89: 3876-3885. DOI: $10.3168 /$ jds.S0022-0302(06)72430-4

Dibia, I.N., N.L. Dartini and N.M. Asrani, 2015. Cattle reproductive disorders in Lombok Island West Nusa Tenggara Province. Buletin Veteriner, 27: 1-10.

Domènech, A., S. Pich, A. Arís, C. Plasencia and A. Bach et al., 2011. Heat identification by $17 \beta-$ estradiol and progesterone quantification in individual raw milk samples by enzyme immunoassay. Electronic J. Biotechnol., 14: 1-5. DOI: 10.2225/vol14-issue4-fulltext-6

Donaldson, R., 2014. Beef Cattle Breeding: Principles and Problems. 1st Edn., Rowell Press, Sydney, pp: 324.

Feradis, 2014. Cattle Reproduction. 1st Edn., Alfabeta, Bandung, ISBN-10: 9786028800082.

Fortune, J.E., G.M. Rivera and M.Y. Yang, 2004. Follicular development: The role of the follicular microenvironment in selection of the dominant follicle. Anim. Reproduct. Sci., 83: 109-126.

DOI: 10.1016/j.anireprosci.2004.04.031

Frandson, R.D., W.L. Wilke and A.D. Fails, 2009. Anatomy and Physiology of Farm Animals. 7th Edn., Willey-Blackwell, New Jersey, ISBN-13: 9780813813943, pp: 436.

Fricke, P.M., 2005. Potential applications and pitfalls of ultrasound for managing reproduction in dairy Cattle. Vet. Clinics North Am. Food Anim. Pract., 21: 419-36. DOI: 10.1016/j.cvfa.2005.02.005

Ghanem, M.E., E. Tezuka, B. Devkota, Y. Izaike and T. Osawa, 2015. Persistence of uterine bacterial infection and its associations with endometritis and ovarian function in postpartum dairy cows. J. Reproduct. Dev., 61: 54-60. DOI: $10.1262 /$ jrd.2014-051

Hafez, E.S.E. and B. Hafez, 2000. Follicullogenesis, Egg Maturation and Ovulation. In: Reproduction in Farm Animal, Hafez, B. and E.S.E. Hafez (Eds.), Lippincott Williams and Wilkins, Philadephia, PA, ISBN-13: 9780683305777, pp: 68-81.

Hermadi, A.H., M. Hariadi and Wurlina, 2011. Application of human menopose gonadotrophin (hmg) toward follicle growth in cows ovary hypofunction. Vet. Medika, 4: 239-245.

Hossner, K.L., 2005. Hormonal Regulation of Farm Animal Growth. 1st Edn., CABI Publishing, USA, ISBN-10: 0851990800, pp: 240.
Inskeep, E.K., 2004. Preovulatory, postovulatory and postmaternal recognition effects of concentrations of progesterone on embryonic survival in the cow. J. Anim. Sci., 82: E24-E39. DOI: $10.2527 / 2004.8213$ supplE24x

Kajaysri, J., 2006. Comparison of estradiol concentrations and conception rate between cows with different estrus behaviors. Vet. J., 16: 15-22.

Kuswati and T. Susilawati, 2016. Industri Sapi Potong. 1st Edn., UB Press, Malang, ISBN-13: 9786024320973.

Murayama, C., E. Yamasaki, A. Miyamoto and T. Shimizu, 2015. Effect of Dedicator Of Cytokinesis 6 (DOCK6) on steroid production in theca cells of follicular cysts. Biochem. Biophys. Res. Commun., 462: 415-419. DOI: 10.1016/j.bbrc.2015.05.005

Noakes, D.E., T.J Parkinson and G.C.W. England, 2016. Veterinary Reproduction and Obstetrics. 9th Edn., Elsevier, London, ISBN-13: 9780702028878, pp: 103.

Nora, M., K. Rachid, G. Abdelmoumène, B.M. Hocine and A.M. Yassine, 2018. Characterization of ovarian follicular and cystic fluids in cows. Veterinaria, 67: 73-79.

Roelofs, J., F. Lopez Gatius, R.H. Hunter, F.J. VanEerdenburg and C. Hanzen, 2010. When is a cow in estrus? Clinical and practical aspects. Theriogenology, 7: 327-344. DOI: 10.1016/j.theriogenology.2010.02.016

Royal, M.D., A.O. Darwash, A.P.F. Flint, R. Webb and J.A. Woolliams et al., 2000. Declining fertility in dairy cattle: Changes in traditional and endocrine parameters of fertility. Anim. Sci., 70: 487-501. DOI: $10.1017 / \mathrm{S} 1357729800051845$

Russell, D.L. and R.L. Robker, 2007. Molecular mechanisms of ovulation: Co-ordination through the cumulus complex. Human Reproduct. Update, 13: 289-312. DOI: 10.1093/humupd/dml062

Saacke, R.G., 2008. Insemination factors related to timed AI in cattle. Theriogenology, 70: 479-484. DOI: 10.1016/j.theriogenology.2008.04.015

Santoso, S., A. Amrozi and H. Herdis, 2014. Gambaran ultrasonografi ovarium kambing Kacang yang disinkronisasi dengan hormon prostaglandin F2 alfa (PGF2 $\alpha$ ) dosis tunggal. J. Kedokteran Hewan, 8: 38-42.

Sayuti, A., J. Melia, Amrozi, Syarifuddin and Roslizawaty et al., 2012. Gambaran klinis sapi Piometra sebelum dan setelah terapi dengan antibiotik dan prostaglandin secara intra uteri. J. Kedoteran Hewan, 6: 99-101.

Sheldon, I.M., G.S. Lewis, S. LeBlanc and R.O. Gilbert, 2006. Defining postpartum uterine disease in cattle. Theriogenology, 65: 1516-1530. 
Siregar, T.N., M.G. Eldora, J. Melia, B. Panjaitan and Yusmadi et al., 2012. Kehadiran folikel dominan pada saat inisiasi superovulasi menurunkan respons superovulasi sapi Aceh. J. Kedokteran Hewan, 6: 67-71.

Susilawati, T., 2011. Tingkat keberhasilan inseminasi buatan dengan kualitas desposisi semen yang berbeda pada sapi peranakan Ongole. J. Ternak Tropika, 12: 05-24.

Susilawati, T., 2013. Pedoman Inseminasi Buatan Pada Ternak. 1st Edn., UB Press, Malang, ISBN-13: 9786022034582.
Yekti, A.P.A., T. Susilawati, M.N. Ihsan and S. Wahjuningsih, 2017. Fisiologi Reproduksi Ternak: Dasar Manajemen Reproduksi. 1st Edn., UB Press, Malang, ISBN-13: 9786024322458.

Zare, S., A. Sadeghipanah, H.J., Barfourooshi and M.A. Emami-Mibody, 2008. Effects of equine Chorionic Gonadotropin (eCG) administration and flushing on reproductive performance in Nadooshan goats of Iran. African J. Biotechol., 7: 3373-3379. 